\title{
Effect of Firm Size on Risk and Return: Evidences from Sultanate of Oman
}

\author{
Ramesh Gengatharan ${ }^{1 *} \quad$ Ekhlass Said Al Harthi ${ }^{2} \quad$ Seham Said Al Malki ${ }^{2}$ \\ 1. Department of Business Studies, Ibra College of Technology, Sultanate of Oman \\ 2.Bachelor Students, Department of Business Studies, Ibra College of Technology, Sultanate of Oman
}

\begin{abstract}
The size of the firms is one of the important factors that determine the firm performance. This study covers the listed firms in MSM. These firms were classified into finance sector, industrial sector and services sectors. The information of the study was collected for a period of 10 years starting from 2008. MSM 30 Index is considered as the benchmark index in Sultanate of Oman. Out of 30 components firms in MSM 30 Index, the required data was available for 24 firms only. Therefore, the study was undertaken with the sample size of 24 firms. The descriptive statistics show that the larger firms risk and return is less while the smaller firms risk and return is high. The result of analysis shows that there is enough evidence to conclude that the firm size has no significant effect on return during the study period. However, the firm size has significant effect with market risk of firms.
\end{abstract}

Keywords: Firm Size, Risk, Return, MSM, Effect of Firm Size, MSM-30 Index

DOI: $10.7176 / \mathrm{EJBM} / 12-9-08$

Publication date:March $31^{\text {st }} 2020$

\section{Introduction}

The Sultanate of Oman witnessed a fast economic growth for the past two decades as a result of higher oil price and the government's policy. Foreign countries were allowed to invest in Oman and similarly Omanis commercial companies were allowed to invest in foreign countries. These policy changes played an active role on economic development of Oman. The country's economy mostly depends on oil revenue as its main source of income. However, the government made many initiatives to start different project to diversify its economy. Recent development in the growth of small and medium enterprise motivate the government to establish special financial support to small and medium sized enterprises. This encourages Omanis to start their own businesses and come out with new ideas to improve the economy. In recent years' people in Oman began aware about the importance of diversifying the sources of income. Saving and investing are two sides of a coin, they play important role in people financial plans. Savings happens when a portion of earned money is not spent. People realized the importance of savings and thus it becomes a regular habit to keep some part of earning that can be utilized to meet future needs. To safeguard the savings and to cope up with the decrease of money value (purchasing power), these savings have to be invested wisely.

Investing is one of the popular choice for the people to increase their wealth. Investments can be made in different ways, and one of attractive source of investments is investing in securities. However, risk is the major concern that may affect securities earnings. Selecting securities to invest in does require deep study and having good awareness of current economic trends. Securities market has its ups and downs, but a patient investor who invest as a long-term investment can earns a higher rate of return than someone who puts his money in a bank savings account. Most challenging task for the investor is deciding or selecting frim(s) to invest their money. To take such decision, there are many aspects that has to be considered. This includes company reputation, performance in the market, company management abilities, firm size, the ability of the company in generating required return and its ability to sustain in the market etc.

It is a common thinking that the firm size impact on the performance of the company. So, the investor base their investment decision based on the firm size too. Therefore, understanding the relationship between firm size, return and risk is very important to the investors to earn maximum return and bear minimum value of risk on their investment.

In Oman, Muscat Securities Market classifies the listed firms into three main sectors: Financial Sector, Industrial Sector and Services Sector. These firms can be classified into large, medium and small using different factors. First, the market capitalization of the firm may be used as tool for measuring firm size. However, capitalization again depends upon the market condition which changes time to time. Second, productive capacity is more useful for determining firm size to industrial firms that produce different product. Knowing how much product factory can produce is effective measuring tool. Third, volume of output to measure firm size is more effective when the firm's products are characteristics in nature. However, in case firms are producing products which are different in nature, this measurement will not deliver the perfect picture about firm size. Fourth, amount of raw material consumed is applied in case outputs of firms are similar in nature and they need for similar input for being produce.

The main goal for investors when investing their money is to earn more money. In addition, investing in 
securities market is one of popular choices for investors because they may get consistent dividend payments by companies which they invest in. Although, income from stocks or securities produce higher rate of returns than money market and bonds, they are still considered relatively conservative investments. Another source of investment which can be generated from the sales of capital asset or income generated from real estate, this kind of investment known as capital gain.it can be short term investment (within one year) or long term investment (more than one year). As we mention before, firm size and return have a positive relation, large size firms will have more opportunity in the market to generate more capital as well as promoting their products or their services than small size firms. Moreover, risk and return are highly related, more return opportunity means more risk opportunity and vice versa. So having enough awareness about risk and return as well as firm size will guide investors to take better investment decision. Most of people prefer to invest their money than save it. Saving will not increase their money in the future so they tend to invest it in many ways. Each investment carries a degree of risk. Investing money in stock exchange market is one of the most important choices people are making at the present time.

Risk in investment world means when investors earn less than expected from his investment or sometimes, losing part or all of the original investment. Return means the income earned from the investment. Risk and return are highly interrelated, when there is expectation of high return, high risk also will be there they are moving hand in hand. Understanding risk and return will help the investors in making investment decisions as well as increasing their wealth.

\subsection{Objective of the study}

1. To analyze the risk and return among the firms listed in MSM.

2. To examine the effect of firm size on the risk and return.

\subsection{Scope of the study}

This study covers the listed company in Muscat Security Market. The firms in MSM benchmark index, MSM 30 Index, are considered for this study. These firms were classified into three main sectors: finance sector, industrial sector and services sectors. The information of the study were collected for a period of 10 years starting from 2008 to 2017. So, this study is expected to examine the influence of firm size factor in Sultanate of Oman for a longer period of time.

\subsection{Rational of the study}

The purpose of conducting this study to examine the impact of firm size in risk and return in listed companies in Muscat Security Market-30 Index. This study will be very helpful for the investor to decide in which company they have to invest in order to generate maximum return with minimum level of risk as study main objective is to study the effect of firm size in risk and return.

\subsection{Limitations}

The study is conducted with selected companies in MSM-30 Index component companies. The result of the study may change if the number of the company's increase. The criteria used in classifying the size of the firm is based only on capitalization, so if we use other criteria the result of the study will be affected. The study covered the period from 2008 to 2017 . In order to get accurate and precise result, the study may need more time. Some economic factor cannot be controlled like inflation and recession, which may change the direction of the study.

\section{Review of Literature}

A research conducted by Chaibi, Alioui \& Xiao (2015) on impact of firm size on risk and return highlights some Fresh Evidences from American stock market. They used 2664 firms as sample firms among the constituent of Russell 3000 Index. The firms were classified into ten categories based on its capitalization. Data were collected on daily basis related to the period of 2010-2012. They found that there is an inverse relationship between the firm size and its return. Small firm tend to generate less return compared to the large one and vice versa. Also they indicate that the price index for a big firms showed higher level of performance than small one. Interestingly, they envisaged that the risk differences cannot be associated to explain the high performance for small firm. The firms with high value tend to perform very well than firms with a small value during the study period.

A research aimed to test the firm size effect on stock market return at the Nairobi securities exchange was conducted by Wairimu (2017). They classified the listed stocks into four quartiles and used the first and fourth quartile as the sample stocks mainly to know the firm size effect among the largest and smallest firms in Nairobi. The used data from Nairobi securities exchange for the period 2009--2016. The researcher found that there was a strong and positive relationship between market return and small firms return. He estimated that $96.4 \%$ of the total market variance could be explained by the small firms' stock return and largest firms' stock return. He concludes that the return from small firms significantly affects the market return. 
Zadeh and Eskandari (2012) the effect of firm size in risk disclosure level. They mentioned that size factor is a very important variable in determining business activity and most studies treat size as a critical factor and used it as invariable factor or control factor Firm with big size tend to disclose more information as they seek for more investor. Intention to merge with other company and many other reasons for disclosure of information that provides numerous benefit for the company. Large firms with large disclosure will help to reduce the level of uncertainty about the performance of the firm. Results of most studies prove that there is a positive relationship between size of firm and risk disclosure level.

A study conducted by Abdullahi, Lawal, and Etudaiye-Muhtar (2011) among Nigeria firms consider sectorwise analysis of firm size effect on risk and return. The study covers the period from 2000 to 2004 . They used monthly data of 60 sample companies that are registered in Nigerian stock exchange. These 60 firm are distributed over 20 different sectors. The researchers use capitalization as a proxy to decide the firm's size. They found that the sectors size measured by using capitalization as a proxy did not effect on sectoral return. Similarly, the risk of the Nigerian firms did not significantly influence by the sectoral firm size. They also maintained that the over performance of return for a small firms and the underperformance of return for large firms may because of policy of the federal government of Nigeria in 2004 and there would be other economic factors that could have an influenced in the risk and return factors. Based on the result of the study, they concluded that the investing in large firms may not provide large return.

Lafrance, (2013) mentioned that at present time small and medium sized firms get more attention by the investor because of its ability to grow faster and make profits quickly. The researcher studied the Firm Size and the Risk/return Trade-off This study was focussed on the risk and return model (greater risk/ greater return). The Information used in this study provided from incorporated firms in Canada that hire employees and the firm size have been calculated by measuring the employment. The study covers the period of 2000 to 2009 . Lafrance found that small firm could achieve greater return than a big firm by taking large risk to compete with large one. He also mentioned that the risk/return model is very important to explain the variance on profitability among different firm size. But there are other factor that cause earning of small firm to become high.

Anton, Tomas \& Jiri (2017), studied the Firm Size and Stock Returns using Meta-Analysis. They conducted the study using 1,746 estimates from 102 previous studies. They tried the study on published journals during 1981 or after. They use three techniques to classify selected journals: funnel plots, meta-regression, and Hedges. The importance of funnel plots is to provide a visual test to the journals. Moreover, researchers used meta-regression to examine the statistical relationship between the ratio of estimates and their standard errors. And to test the relationship between individual estimates and their statistical importance they used Hedges. Finally, they argue that abnormality on prices of assets become less abnormal when published. This concept help to report significant or even negative estimates of the effect of firm size on return, then reducing publication bias.

Shafana, Rimziya \& Jariya (2013), examined the Relationship between Stock Returns and Firm Size, and Book-To-Market Equity in Sri Lankan market. They conducted the study with 12 firms out of 25 firms (financial firms and non-financial firms) including six years annual data of these firms which listed on Milanka Price Index starting from the year of 2005 in Colombo Stock Exchange. They used stock returns treated as dependent variable and independent variables are firm size and book-to equity. In this study, the researchers used cross-sectional regression model to examine the relationship between firm size and stock returns. They found that no relation between return and firm size, but there is a negative relation between return and book-to market value.

Nguyen \& Nguyen (2016) conducted a study to examine the relationship between firm size and stock turns in Ho Chi Minh Stock Exchange in Vietnamese. The study conducted with 160 companies in service sector from the period 2009 to 2014. They employed multiple regression model to test the relationship between firm size and stock turns, dependent variable in their study was stock return and independent variables was firm size. Actually, there are so many indicators to measure the firm size but the preferred total assets rather than other indicators to avoid inflation or deflation of securities. Finally, researchers found there is negative relationship between firm size and stock returns in Vietnamese market. They pointed out that the small companies could attract more investors and earn higher returns than large companies.

Batsirai, Davis (2014) tested the relationship between firm size and stock returns for 64 companies listed on the Zimbabwe Stock Exchange, out of which 60 are industrial companies and 4 are mining companies. The study period ranges between June 2009 and July 2013. They used mining index as market proxies for mining stock and industrial index for industrial stocks. For analyzing data multiple regression model was employed. They found that the effect on stock returns on the Zimbabwe Stock Exchange by firm size was positive but insignificant. On the other hand, larger firms show higher risk-adjusted returns than smaller firms in Zimbabwe.

Kewei, Mathijs (2008) studied the relationship between Firm Size, Profitability Shocks, and Expected Stock Returns in U.S firms. They classified the stocks based on size and tested the returns over two periods of equal length (1963-1983 and 1984-2005). They used the cross-sectional profitability model to analyse the data. They found that that profitability shocks are close to zero for large and small companies over 1963-1983, but there is a positive relationship between profitability shocks and firm size after the year 1984-2005. They detected an 
important size premium of around 10\% per annum for 1984-2005. And the size effect for the period after 1984 was strong to alternative profitability models, different return adjustments, and different test methods.

\section{Research Methodology}

This study is conducted to examine the effect of firm size on risk and return in among the firms listed in Muscat Security Market. Therefore, this research is an analytical study in nature.

\subsection{Sample}

The listed companies in MSM are considered as the population of the study. The total number of listed companies in MSM is 117 as on $31^{\text {st }}$ October, 2018. These companies were classified into 3 sectors: financial sector, industrial sector and services sector. Since, it is practically difficult to carry out the research with all the listed companies in MSM; it is decided to use representative sample firms. As the MSM 30 Index is considered as the benchmark index in Sultanate of Oman, it is presumed that the component firms in MSM 30 Index are the representative firms for the country. Out of 30 components firms in MSM 30 Index, the required data was available for 24 firms only. Therefore, the study was undertaken with the sample size of 24 listed firms in MSM 30 Index.

\subsection{Period of Study}

Based on the availability of resources, the present research has been carried out with ten years' data. The study period is 2008 to 2017.

\subsection{Sources of Data}

This study uses secondary sources of data. The required information is gathered from MSM website.

Sector-wise list of sample firms (Components of MSM 30 Index);

1. Al Madena Investment

2. Bank Dhofar

3. Bank Muscat

4. Bank Sohar

5. Gulf Invest Services Holding

6. HSBC Bank Oman

7. National Bank Of Oman

8. Al Anwar Holding

9. Ahli Bank

10. Oman And Emirates Inv.Holding

11. Ominvest

12. Al Sharqia Investment

13. Raysut Cement

14. Oman Fisheries

15. Oman Flour Miles

16. Al Anwar Ceramic Tiles

17. Oman Cement

18. Galfar Engineering And Con

19. Al Jazeera Services

20. National Gas

21. Oman Investment And Finance

22. Oman Telecommunication

23. Renaissance Services

24. Shell Oman Marketing

\subsection{Data Analysis}

The collected secondary data has been analyzed using SPSS statistics (version 20). Multiple regression analysis, correlation analysis has been employed apart from descriptive statistics. The multiple regressions are a stretch of simple linear regression. It is applied when prediction of value for one variable is done according to the value of other two or more variables. The correlation analysis is a method of evaluation of statistical data and it used to examine how strong is the relationships between variables. In addition, standard deviation model is used risk in calculation.

\subsection{Variables used in the study}

Independent variable, that is stable and not affected by the other variables but will affect other dependent variables and researcher want to measure such effect. In relation to our study the independent variable is firm size, which 
classified into three classifications: small, medium and large firms. Dependent variables which are affected by independent variables, and in this study risk and return are the dependent variables.

\subsection{Calculation of Risk}

This study aims to determine the effect of firm size on risk and rates of return. Various measures can be used to determine risk. Fisher and Hall (1969) argued that greater variance in the distribution of earnings is indicative of greater risk. Many other researchers have adopted this measure of risk (Samuels and Smyth 1968; Hurdle 1974; Shapiro 1980). Hence, the risk is calculated as follows.

Where,

$$
\sigma_{i}=\left\lceil\sum_{t=1}^{n} \frac{\left(r_{o}-\bar{r}_{i}\right)^{2}}{n}\right\rceil^{1 / 2}
$$

$r_{i}$ is the observed rate of return for firm $i$ in year $t$;

$\bar{r}_{i}$ is the average rate of return over the time $\mathrm{t}$ firm $\mathrm{i}$;

$\sigma_{i}$ is the standard deviation of rates of return for firm $\mathrm{i}$; and

$\mathrm{n}$ is the number of years included in the sample.

\subsection{Calculation of Return}

Annual stock return for each year can be obtained using share price as follows;

Return $=$ Close price - Previous price $/$ Previous price $\mathrm{x} 100$

\subsection{Market Capitalization}

The market capitalization of the sample firm is obtained from MSM website.

\section{Analysis and Interpretations}

The firms were classified using percentile analysis. The firm size effect on risk and return is analyzed using oneway ANOVA. Moreover, multiple regression analysis is done to predict the impact of stock return. The following table shows the classification of the firms.

Percentiles analysis is a tool used to classify a set of data into different groups. This indicates that the value below a given percentage of observations that belongs to a specific group. Using market capitalization of the sample firm, percentiles analysis was performed. Table I presents that $25^{\text {th }}$ percentile value is OMR $14,511,718$ and hence the firms with market capitalization of $25^{\text {th }}$ percentile value or less were classified as small firms. The firms with $75^{\text {th }}$ percentile value of OMR $241,408,278$ or more were classified as large firms while the firms with market capitalization between the $25^{\text {th }}$ percentile value and $75^{\text {th }}$ percentile value (i.e. more than OMR $14,511,718$ but less than OMR 241,408,278) were categorized as medium sized firms. Table II shows the number of firms belong to each of these categories. It shows that out of 24 total sample firms, 6 firms belong to large firm category, 12 firms are in medium category firms and the rest 6 firms are in the category of small firms.

Table III presents the summary statistics of risk and return of sample firms during 2008 to 2017 . It seen that the average return ranges between $-18.77 \%$ and $40.91 \%$. The highest mean return is seen from Al Jazeera Services which was 40.91\%, 26.35\% for Oman Flour Miles, followed by $13.77 \%, 10.64 \%$ and 8.32\% respectively for Oman Fisheries, National Gas and Al Anwar Holding. On the other hand, the lowest average return could be seen as $-18.77 \%$ for Galfar Engineering and Construction company, $-11.70 \%$ for Bank Muscat followed by $-10.49 \%$, $7.93 \%$ and $-4.82 \%$ for National Bank of Oman, HSBC Bank Oman and Al Madena Investment respectively. From minimum return statistics the lowest return was $-80.84 \%$ for Gulf Invest Services Holding, $-80.80 \%$ for Oman and Emirates Investment Holding, - $76.31 \%$ for Al Madena Investment and $\mathbf{- 7 0 . 5 6 \%}$ for Oman Investment and Finance followed by $-68.97 \%$ for Galfar Engineering and Construction. Maximum return data shows that the maximum return of 384.21\% was for AlJazeera Services, then Oman Flour Miles with $211.71 \%$ followed by Al Anwar Holding, Oman Investment and Finance and Oman Cement with 183.33\%, 152.67\% and 148.50\% respectively. In this study, standard deviation is used to measure the risk. From the summary statistics of risk and return during 2008 to 2017, the standard deviation ranged between 137.15 and 9.01. It can be noted that Aljazeera Services presents the highest standard deviation between the listed companies by 137.15, Oman Flour Miles by 72.32, and 71.47 related to Al Anwar Holding. Followed by 59.07 and 58.28 for National Gas and Gulf Invest Services Holding respectively.

After classifying the firms based on their market capitalization into three main categories, table IV summarize statistical data on the basis of Firm Size during 2008 to 2017. The small firms tend to reflect positive average return of 3.73\% compared with MSM-30 index -3.94\% and higher average return than composite firms (1.86\%). Medium firms show positive average return of $4.34 \%$ compared with MSM-30 index $-3.94 \%$ and higher average return than composite firms (1.86\%). When comparing the average return of large firm with MSM 30 Index and composite firms, large firms have negative average return $(-4.96 \%)$ which is worse than the MSM-30 index (- 
3.94\%) and composite (1.86\%). During 2008 to 2017 the minimum average return of small firms was $-76.31 \%$ which is less than $-39.78 \%$ of MSM 30 Index and more than composite firms negative return of $-80.84 \%$. The minimum return of medium firms $-70.56 \%$ is less than MSM 30 Index -39.78 and higher than Composite (-80.84\%). The large firms present minimum return of $-45.09 \%$ which is less than MSM 30 Index (-39.78) and higher than composite firms return (-80.84\%). Small firms tend to present higher maximum return of $141.67 \%$ compared with MSM-30 index $-18.64 \%$ and lower maximum return than composite firms (384.21\%). Medium firms show higher maximum return of $384.21 \%$ compared with MSM-30 index $18.64 \%$ and equal maximum return to composite firms (384.21\%). When comparing the maximum return of large firm with MSM 30 Index and composite firms, large firms have higher maximum return $(98.10 \%)$ than MSM-30 index $(18.64 \%)$ and lower than composite (384.21\%). During 2008 to 2017 the standard deviation of small firms was 18.48 which is higher than 17.66 of MSM 30 Index and less than composite firms by 51.56. The standard deviation of medium firms (59.46) is more than both MSM 30 Index and Composite by (17.66) and (51.56) respectively. The large firms size presents lower standard deviation of 17.41 than MSM 30 Index (17.66) and higher than Composite (51.56).

\subsection{Analysis of Impact of Firm Size on Return}

The impact of firm size on mean return was analyzed using One Way Analysis of Variance (ANOVA) test. This test is performed to determine whether there exists significant difference between the mean return among the three groups of firms (i.e., Small, Medium and Large).

$\mathrm{H}_{0}$ : There is no significant differences in mean return among firm sizes.

The summery statistics resulting from our dataset are presented in table $\mathrm{V}$. The mean return of different firms during the study period are given according to their size categories. The small firms tend to earn more positive return $(8.77 \%)$ when compared to medium and large sized companies. The mean return of large sized companies reflects negative return $(-4.95 \%)$. The mean return of medium sized companies was $-1.81 \%$. It shows that the small firms yielded better return during the study period whereas the larger firms eroded the investors' wealth by providing the negative return during the study period. By looking at the mean return, it is evident that the small firms are the safe haven for investment than the larger firms in terms of proving return to the shareholders. However, the result of the AVOVA test presented in table VI shows that the significance value is (p-value) is more than 0.05. Therefore, the null hypothesis is accepted and hence statistically there is enough to conclude that the firm size has no significant effect on return during the study period among the listed firms in MSM.

\subsection{Analysis of Impact of Firm Size on Risk}

The impact of firm size on risk was also analyzed using ANOVA test. This test is performed to determine whether there exist significant differences between the risks among the three groups of firms (i.e., Small, Medium and Large).

$\mathrm{H}_{0}$ : There is no significant differences in risks among firm sizes.

It is observed from table VII that large firms have lowest standard deviation (11.02) compared to small and medium firms. In another hand, small firms tend to carry the highest standard deviation (34.54) between categorized firms size. The standard deviation of medium firm was 19.39. It shows that the risk in large firms is less than other categories of firm during the study period. On the other hand, the small firms were exposed to higher risk which is estimated equivalent to three times of large firms mean risk. Similarly, the medium firms risk is lesser than the small firm but higher than the large firms. By looking at the risk, it is evident that the small firms are riskier for investment than the medium and larger firms. The result of the AVOVA test presented in table VIII shows that the significance value is less than 0.01. The null Hypothesis is not accepted at $1 \%$ level of significance. Hence, it is concluded that the firm size has significant effect with market risk of different categories of the firms listed in MSM.

\subsection{Analysis of Strength of Relationship between Firm Size, Return and Risk}

The study of level of relationship between the study variables was analyzed using correlation. The values of correlation coefficient ranges between +1 and -1 where the +1 signifies the highest positive correlation and the -1 represents the highest negative correlation between the two variables. Table IX depicts the multiple correlation and significance value. It shows that the correlation coefficient between market capitalization and mean return is -.359 and the significance value is $0.085(\mathrm{p}>.05)$ which indicate there is no significant relationship between firm size and average return. The correlation coefficient between market capitalization and market risk is -.482 and it is significant at $5 \%$ level $(\mathrm{p}<.05)$. This indicates that there exist moderate negative relationship between market capitalization and market risk. This proves that the risk among the larger firms are lesser and vice versa. The correlation coefficient between market risk and return is .816 and it is significant at $1 \%$ level $(p<.01)$. This indicates that the risk and return is highly positively correlated. This proves the general fact that higher return investments are exposed to higher risks. 


\subsection{Analysis of impact of firm return}

There are many factors which contributes for the return. However, an attempt is made to analyse the impact of return with the available data (i.e. Market Capitalization and Market Risk) as this would help the investors to predict the firms return (dependent variable) based on the independent variables (Market Capitalization and Market Risk). Multiple Regression analyses used to measure the statistical relationship between two or more variables. The results presented in table X shows that the Market Capitalization and Market Risk could predict the return by $66.8 \%$. The output of ANOVA shows that the significance value $(\mathrm{F}=21.094$ and $\mathrm{p}=.000)$ is less than .01 . This confirm that this model has significant predictive capacity in predicting the dependent variable.

\section{Conclusion}

In this research an attempt is made to study the effect of firm size into risk and return. This study was conducted with 24 firms from MSM-30 index and the study the period is 10 years i.e., 2007 to 2017. Return was estimated from stock prices and standard deviation is used to measure market risk. Market capitalization was used to determine firm size. The descriptive statistics show that the large firms risk and return is less while the smaller firms risk and return is high. The result of analysis shows that there is enough evidence to conclude that the firm size has no significant effect on return during the study period. However, the firm size has significant effect with market risk of firms listed in MSM.

\subsection{Scope for further research}

Based on our study, we would like to highlight that further researches could be done in the following areas. Other measures like asset size, revenue could be used as a proxy for firm size instead of market capitalization. Sectoral comparison of firm size effect could be addressed. Firm size effect of MSM listed firms could be compared with other GCC firms.

\section{References}

Abdullahi, I. B., Lawal, W. A., \& Etudaiye-Muhtar, O. F. (2011). The effects of firm size on risk and return in the Nigerian Stock Market: A sectoral analysis. British Journal of Economics, 1(2), 1-10.

Astakhov, A., Havranek, T., \& Novak, J. (2017). Firm Size and Stock Returns: A Meta-Analysis (No. 14/2017). IES Working Paper. Retrieved on 6 October, 2018, from http://meta-analysis.cz/size/size.pdf.

Chaibi, A., Alioui, S., \& Xiao, B. (2015). On the impact of firm size on risk and return: Fresh evidence from the American stock market over the recent years. Journal of Applied Business Research (JABR), 31(1), 29-36.

Duy, N. T., \& Phuoc, N. P. H. (2016). The relationship between firm sizes and stock returns of service sector in ho chi minh city stock exchange. Rev. Eur. Stud., 8, 210.

Hou, K., \& Van Dijk, M. A. (2007). Resurrecting the size effect: Firm size, profitability shocks, and expected stock returns. Profitability Shocks, and Expected Stock Returns (08/08/2007). Retrieved on 11 November, 2018 from http://www.ruf.rice.edu/ jgsfss/hou_ 100608.pdf.

Lafrance, A. (2013). Firm Size and the Risk/return Trade-off. Statistics Canada, Analytical Studies Branch. Retrieved on 10 October, 2018 from https://www150.statcan.gc.ca/n1/pub/11f0027m/2013087/part-partie1eng.htm

Mazviona, B. W., \& Nyangara, D. (2014). Does firm size affect stock returns? Evidence from the Zimbabwe Stock Exchange. International Journal of Business and Economic Development (IJBED), 2(3).

Shafana, M. A. C. N., Rimziya, A. F., \& Jariya, A. I. (2013). Relationship between stock returns and firm size, and book-to-market equity: empirical evidence from selected companies listed on Milanka Price Index in Colombo Stock Exchange. Journal of Emerging Trends in Economics and Management Sciences, 4(2), 217225.

Wairimu, M. B. (2017). Testing the firm size effect on stock market returns at the nairobi securities exchange (Doctoral dissertation, School of Business, University Of Nairobi). Retrieved on 10 October, 2018 from http://erepository.uonbi.ac.ke/

Zadeh, F. O., \& Eskandari, A. (2012). Firm size as company's characteristic and level of risk disclosure: Review on theories and literatures. International Journal of Business and Social Science, 3(17).

Table I: Classification of firm by Size

\begin{tabular}{|l|l|c|}
\hline \multirow{4}{*}{ Percentiles } & Valid & 24 \\
\cline { 2 - 3 } & Missing & 0 \\
\hline & 25 & $14,511,718$ \\
\cline { 2 - 3 } & 50 & $89,361,779$ \\
\cline { 2 - 3 } & 75 & $241,408,278$ \\
\hline
\end{tabular}


Table II: Firm Category

\begin{tabular}{|l|c|}
\hline \multicolumn{1}{|c|}{ Category of Firms } & No. of Sample Firms \\
\hline Small & 6 \\
\hline Medium & 12 \\
\hline Large & 6 \\
\hline Total Sample Firms & 24 \\
\hline
\end{tabular}

Table III: Risk \& Return: Summary statistics during 2008 to 2017

\begin{tabular}{|c|c|c|c|c|}
\hline Firm & Mean Return $\%$ & Min $\%$ & Max $\%$ & Std Dev. \\
\hline 1 & -4.82 & -76.31 & 58.44 & 42.61 \\
\hline 2 & -4.29 & -45.09 & 98.10 & 20.74 \\
\hline 3 & -11.70 & -58.49 & 16.75 & 32.17 \\
\hline 4 & 3.48 & -28.64 & 89.08 & 58.28 \\
\hline 5 & -1.21 & -80.84 & 119.15 & 22.95 \\
\hline 6 & -7.93 & -45.25 & 35.00 & 16.68 \\
\hline 7 & -10.49 & -51.37 & 12.98 & 71.47 \\
\hline 8 & 8.32 & -66.90 & 183.33 & 28.70 \\
\hline 10 & -0.52 & -47.72 & 45.64 & 60.81 \\
\hline 11 & 0.76 & -80.80 & 122.73 & 14.06 \\
\hline 12 & -3.87 & -37.26 & 15.84 & 55.33 \\
\hline 13 & 3.24 & -57.14 & 141.67 & 45.85 \\
\hline 14 & 0.77 & -47.30 & 89.47 & 52.74 \\
\hline 15 & 13.77 & -31.31 & 140.98 & 72.32 \\
\hline 16 & 26.35 & -27.30 & 211.71 & 41.28 \\
\hline 17 & -3.86 & -46.52 & 88.34 & 56.44 \\
\hline 18 & 6.52 & -54.67 & 148.50 & 32.54 \\
\hline 19 & -18.77 & -68.97 & 34.29 & 137.15 \\
\hline 20 & 40.91 & -47.37 & 384.21 & 59.07 \\
\hline 21 & 10.64 & -50.17 & 89.40 & 56.85 \\
\hline 22 & 1.70 & -70.56 & 152.67 & 10.57 \\
\hline 23 & -2.86 & -20.46 & 12.62 & 42.76 \\
\hline & -2.90 & -65.61 & 47.24 & 9.01 \\
\hline
\end{tabular}

Table IV: Risk \& Return: Summary statistics on the basis of Firm Size during 2008 to 2017

\begin{tabular}{|l|c|c|c|c|}
\hline \multicolumn{1}{|c|}{ Firm Size } & Mean Return \% & Min \% & Max \% & Std. Dev. \\
\hline Small & 3.73 & -76.31 & 141.67 & 18.48 \\
\hline Medium & 4.34 & -70.56 & 384.21 & 59.46 \\
\hline Large & -4.96 & -45.09 & 98.10 & 17.41 \\
\hline Composite & 1.86 & -80.84 & 384.21 & 51.56 \\
\hline Market - MSM 30 Index & -3.94 & -39.78 & 18.64 & 17.66 \\
\hline
\end{tabular}


Table V: Descriptive - Mean Return

\begin{tabular}{|c|c|c|c|c|c|c|c|c|}
\hline & \multirow[t]{2}{*}{$\mathrm{N}$} & \multirow[t]{2}{*}{ Mean } & \multirow[t]{2}{*}{$\begin{array}{l}\text { Std. } \\
\text { Dev. }\end{array}$} & \multirow[t]{2}{*}{ Std. Error } & \multicolumn{2}{|c|}{$\begin{array}{l}95 \% \text { Confidence Interval } \\
\text { for Mean }\end{array}$} & \multirow[t]{2}{*}{ Minimum } & \multirow[t]{2}{*}{ Maximum } \\
\hline & & & & & $\begin{array}{l}\text { Lower } \\
\text { Bound }\end{array}$ & $\begin{array}{l}\text { Upper } \\
\text { Bound }\end{array}$ & & \\
\hline Small & 6 & 8.7 & 16.9 & 6.9 & -9.0 & 26.5 & -4.8 & 40.9 \\
\hline Medium & 12 & 1.8 & 10.9 & 3.1 & -5.1 & 8.7 & -18.7 & 26.3 \\
\hline Large & 6 & -4.9 & 5.5 & 2.2 & -10.7 & .8 & -11.7 & 3.4 \\
\hline Total & 24 & 1.8 & 12.3 & 2.5 & -3.3 & 7.0 & -18.7 & 40.9 \\
\hline
\end{tabular}

Table VI: ANOVA

\begin{tabular}{|l|r|r|r|r|r|}
\hline & Sum of Squares & df & Mean Square & F & Sig. \\
\hline Between Groups & 565.5 & 2 & 282.7 & 2.038 & .155 \\
Within Groups & 2914.3 & 21 & 138.7 & & \\
Total & 3479.9 & 23 & & & \\
\hline
\end{tabular}

Table VII: Descriptive

\begin{tabular}{|c|c|c|c|c|c|c|c|c|}
\hline & \multirow[t]{2}{*}{$\mathrm{N}$} & \multirow[t]{2}{*}{ Mean } & \multirow[t]{2}{*}{$\begin{array}{l}\text { Std. } \\
\text { Dev. }\end{array}$} & \multirow[t]{2}{*}{$\begin{array}{l}\text { Std. } \\
\text { Error }\end{array}$} & \multicolumn{2}{|c|}{$\begin{array}{l}95 \% \text { Confidence Interval } \\
\text { for Mean }\end{array}$} & \multirow[t]{2}{*}{ Minimum } & \multirow[t]{2}{*}{ Maximum } \\
\hline & & & & & $\begin{array}{l}\text { Lower } \\
\text { Bound }\end{array}$ & $\begin{array}{l}\text { Upper } \\
\text { Bound }\end{array}$ & & \\
\hline Small & 6 & 67.8 & 34.5 & 14.1 & 31.6 & 104.1 & 42.6 & 137.1 \\
\hline Medium & 12 & 44.9 & 19.3 & 5.6 & 32.6 & 57.3 & 9.0 & 72.3 \\
\hline Large & 6 & 22.1 & 11.0 & 4.5 & 10.5 & 33.7 & 10.5 & 38.7 \\
\hline Total & 24 & 44.9 & 27.1 & 5.5 & 33.5 & 56.4 & 9.0 & 137.1 \\
\hline
\end{tabular}

Table VIII: ANOVA

\begin{tabular}{|c|c|c|c|c|c|}
\hline & Sum of Squares & df & Mean Square & $\mathrm{F}$ & Sig. \\
\hline $\begin{array}{l}\text { Between Groups } \\
\text { Within Groups } \\
\text { Total }\end{array}$ & $\begin{array}{r}6267.3 \\
10711.9 \\
16979.2\end{array}$ & $\begin{array}{r}2 \\
21 \\
23\end{array}$ & $\begin{array}{r}3133.6 \\
510.1\end{array}$ & 6.14 & .008 \\
\hline
\end{tabular}

Table IX: Correlations

\begin{tabular}{|c|c|c|c|c|}
\hline & & $\begin{array}{c}\text { Market } \\
\text { Capitalization }\end{array}$ & Mean Return & Risk \\
\hline Market Capitalization & $\begin{array}{l}\text { Pearson Correlation } \\
\text { Sig. (2-tailed) } \\
\mathrm{N}\end{array}$ & & & \\
\hline Mean Return & $\begin{array}{l}\text { Pearson Correlation } \\
\text { Sig. (2-tailed) } \\
\text { N }\end{array}$ & $\begin{array}{r}-.359 \\
.085 \\
24 \\
\end{array}$ & & \\
\hline Risk & $\begin{array}{l}\text { Pearson Correlation } \\
\text { Sig. (2-tailed) } \\
\mathrm{N}\end{array}$ & $\begin{array}{r}-.482^{*} \\
.017 \\
24\end{array}$ & $\begin{array}{r}.816^{* *} \\
.000 \\
24\end{array}$ & \\
\hline
\end{tabular}

*. Correlation is significant at the 0.05 level (2-tailed).

**. Correlation is significant at the 0.01 level (2-tailed). 
Table X: Model Summary

\begin{tabular}{|l|r|r|r|r|r|}
\hline Model & \multicolumn{1}{|c|}{$\mathrm{R}$} & \multicolumn{1}{|c|}{ R Square } & Adjusted R Square & $\begin{array}{c}\text { Std. Error of the } \\
\text { Estimate }\end{array}$ & Durbin-Watson \\
\hline 1 & $.817^{\mathrm{a}}$ & .668 & .636 & 7.42112 & 2.217 \\
\hline
\end{tabular}

a. Predictors: (Constant), Risk, Market Capitalization

b. Dependent Variable: Mean Return

ANOVA
\begin{tabular}{|rl|r|r|r|r|r|}
\hline Model & & Sum of Squares & \multicolumn{1}{|c|}{ Df } & Mean Square & \multicolumn{1}{c|}{ F } & Sig. \\
\hline \multirow{3}{*}{1} & Regression & 2323.454 & 2 & 1161.72 & 21.094 & $.000^{\mathrm{b}}$ \\
& Residual & 1156.532 & 21 & 55.07 & & \\
& Total & 3479.987 & 23 & & & \\
\hline
\end{tabular}

a. Dependent Variable: Mean Return

b. Predictors: (Constant), Risk, Market Capitalization

Coefficients

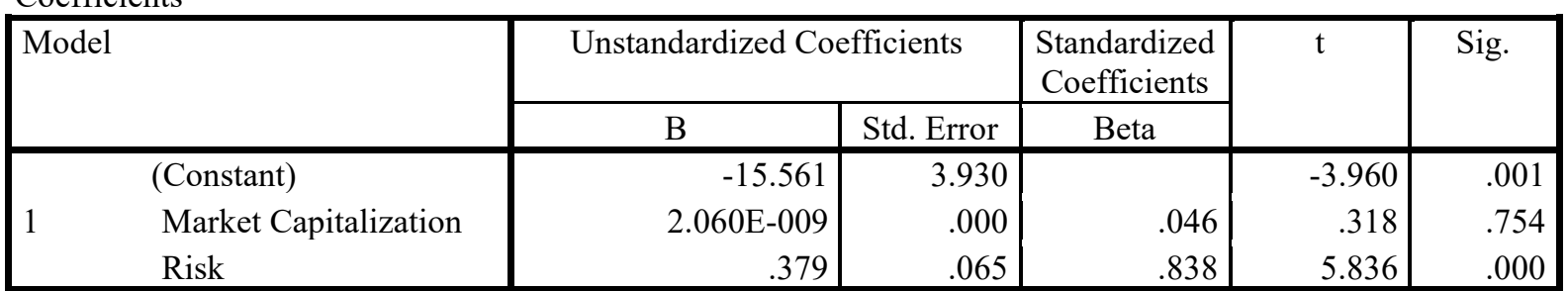

a. Dependent Variable: Mean Return 